\title{
Environmental Dynamics of Pesticides in the Drainage Area of the São Lourenço River Headwaters, Mato Grosso State, Brazil
}

\author{
Karen P. Casara, ${ }^{a}$ Antonio B. Vecchiato, ${ }^{a, b}$ Carolina Lourencetti, ${ }^{a}$ \\ Alicio A. Pinto ${ }^{c}$ and Eliana F. G. C. Dores $*, a, c$ \\ ${ }^{a}$ Programa de Pós-Graduação em Recursos Hídricos, ${ }^{b}$ Departamento de Geologia Geral and
'Departamento de Química, Instituto de Ciência Exatas e da Terra,
Universidade Federal de Mato Grosso, Campus de Cuiabá, 78060-900 Cuiabá-MT, Brazil
}

Este estudo avaliou a dinâmica de pesticidas na cabeceira de drenagem do Rio São Lourenço, Mato Grosso, Brasil. Os pesticidas atrazina, flutriafol, metolacloro, $\alpha$ - e $\beta$-endosulfan e os metabólitos endosulfan sulfato, desetilatrazina e desisopropilatrazina foram determinados em amostras de água (superficial, subterrânea, de chuva e de escoamento superficial) e de sedimento (de escoamento superficial e de fundo) coletadas entre agosto de 2009 e julho de 2010 utilizando SPE-GC/MS-SIM (extração em fase sólida-cromatografia gasosa acoplada à espectrometria de massas em modo de monitoramento seletivo de íons). Os resultados demonstraram que o escoamento superficial e a deposição atmosférica são processos importantes de entrada de pesticidas na água superficial, principalmente por pesticidas altamente adsorvidos nas partículas de sedimento, cuja concentração máxima foi de $2218 \mu \mathrm{g} \mathrm{kg}^{-1}$ para $\beta$-endosulfan, e dissolvidos em água com concentração máxima de $28,3 \mu \mathrm{g} \mathrm{\textrm {L } ^ { - 1 }}$ para atrazina. Endosulfan sulfato, atrazina e metolacloro foram os compostos detectados com maior frequência. A lixiviação foi uma via importante de transporte devido ao comportamento hídrico do solo e ao baixo nível do lençol freático, levando à contaminação de águas subterrâneas bem como de águas superficiais devido ao fluxo em subsuperfície.

This study assessed the environmental dynamics of pesticides in the São Lourenço River headwaters, Mato Grosso State, Brazil. The pesticides atrazine, flutriafol, metolachlor, $\alpha$-and $\beta$-endosulfan and the metabolites endosulfan sulfate, desethylatrazine and desisopropylatrazine were determined in water (rain, surface, ground and runoff) and in sediment (runoff and bottom) samples, collected from August 2009 to July 2010, by SPE-GC/MS-SIM (solid phase extractiongas chromatography/mass detector with selected ion monitoring). Runoff and rain atmospheric deposition showed to be important pathways for surface water contamination mainly by highly sorbed pesticides found in sediment with maximum concentration of $2218 \mu \mathrm{g} \mathrm{kg}^{-1}$ for $\beta$-endosulfan, and in water with maximum concentration of $28.3 \mu \mathrm{g} \mathrm{L}^{-1}$ for atrazine. Endosulfan sulfate, atrazine and metolachlor were the compounds with the highest frequency of detection. Leaching was an important process of off-site transport mainly due to the hydric behavior of soil and the low depth of water table, leading to contamination of groundwater as well as surface water via subsurface flow.

Keywords: pesticide, runoff, leaching, off-site transport, water contamination

\section{Introduction}

Agricultural production is an important source of income, especially in developing countries where several economy sectors such as the tertiary sector benefit from this activity. However, the potential harm to the environment grows with increases in production. In Brazil, the highly

*e-mail: eliana@ufmt.br technological agricultural production is responsible for a great portion of Brazilian export revenue. This type of production demands a great amount of inputs such as pesticides and fertilizers.

Pesticides used in agriculture, after reaching the soil, undergo several chemical, physical and biological processes, which control their fate and their movement to different environmental compartments. Understanding the environmental behavior of pesticides is essential for the 
determination of mitigation measures to reduce or eliminate water contamination risk.

The dynamics of pesticides in soil are controlled by retention, transformation and transportation processes with interaction between them. ${ }^{1}$ Among the transportation processes, leaching and runoff are the most important ones. Runoff is the main route for surface water contamination with pesticides either dissolved in water or adsorbed to suspended sediment particles, while leaching is the main pathway for pesticides to reach groundwater. Losses of active substance by leaching can, in exceptional cases, be as high as $5 \%$ but are typically less than $1 \% .{ }^{2}$ Regarding runoff, this transport can reach 1 to $2 \%$ of the applied dose during a single extreme rain event but is usually less than $0.05 \% .^{3,4}$

Kinetics of these processes are influenced by the soil physical and chemical properties, climate, topography and agricultural practices as well as by chemical and physical properties of the pesticides. The complexity of such multifactorial processes renders the study of environmental fate of pesticides difficult and site-specific studies may be necessary to evaluate specific scenarios.

How vulnerable different areas are, an intrinsic property, depends mainly on soil physical and chemical properties. Headwaters are especially vulnerable areas due to low water table depth. Two thirds of headwater stream contamination with sediments, nutrients and pesticides are caused by nonpoint sources in agriculture. ${ }^{5}$

During the past decades, monoculture in large areas has intensified in Brazil, imposing a greater risk to water quality. ${ }^{6}$ The potential for water resources contamination is even higher in headwater drainage. The occupation of these areas in Mato Grosso State (Brazil) is of great concern, considering that many rivers that feed three important hydrographic basins (Amazon, Paraguay and AraguaiaTocantins) have their springs in this state.

In tropical regions, particularly in Brazil, the pesticide fate has been subject to few studies., ${ }^{4,-17}$ Aiming to contribute to a better understanding of pesticide behavior in tropical areas, this work presents the results of pesticides atrazine and its metabolites desethylatrazine and desisopropylatrazine, flutriafol, metolachlor, $\alpha$ - and $\beta$-endosulfan and its metabolite endosulfan sulfate in a vulnerable tropical environment, emphasizing dissipation processes in the field.

\section{Experimental}

\section{Study area}

The São Lourenço River headwaters are located in the South of the Mato Grosso State, the Center-Western region of Brazil. The São Lourenço River is an important affluent of the Cuiabá River that drains areas from the Chapada dos Guimarães highland and run to the Paraguay River, whose watershed comprehend the Pantanal sedimentary basin.

This area is intensively occupied by highly mechanized cash-crop production farms. In several locations, the marginal vegetation is lacking. In the study area localized at $15^{\circ} 37^{\prime} 06.28^{\prime \prime} \mathrm{S}$ and $55^{\circ} 10^{\prime} 00.44^{\prime \prime} \mathrm{W}$ (Figure 1), there is a small dam, in whose left margin, a vegetation recovery process was initiated in 2009. However, the width of this vegetation is still smaller than the $50 \mathrm{~m}$, minimum required by the Brazilian law. ${ }^{18}$ On the right margin, the vegetation was completely removed.

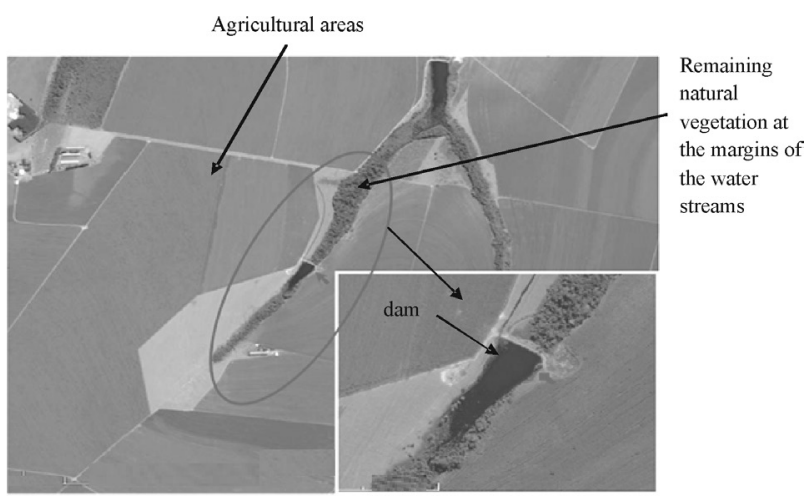

Figure 1. Study area satellite image (the São Lourenço River headwaters) ${ }^{19}$ (for more details (colored image) see Figure S1 in the Supplementary Information (SI) section).

The remaining river-margin vegetation is constituted by a forest formation with predominance of shrubby-arboreous community with species adapted to high soil humidity. However, the agricultural expansion removed almost totally the original vegetal covering from this region (Figure 1).

The climate in this area is classified as tropical with a dry season (Aw according to Köppen-Geiger classification system) and characterized by two distinct seasons considering the precipitation regimen (rainy and dry) with the rainy period concentrated from December to March. Maximum annual temperatures vary from 31 to $33^{\circ} \mathrm{C}$, minimum annual temperatures vary from 16 to $18{ }^{\circ} \mathrm{C}$ and average annual temperatures range from 22 to $24^{\circ} \mathrm{C}$ with an average annual rain of $1700 \mathrm{~mm}$, and a monthly maximum ranging from 16 to $300 \mathrm{~mm}$ and minimum varying from 2 to $50 \mathrm{~mm}$.

To better understand the water movement through soil, the slope of the São Lourenço River headwater left margin was studied by soil perforation using a manual drill. The soil physical characteristics were observed in the field. The pedological horizons were identified based on the morphological description of characteristics in the field such as color, texture and pedological façades that are 
related to water movement through the soil such as presence of plinthite, gleying and latter concretion. ${ }^{20}$

The soil physical properties greatly influence the water movement through the soil profile. In the left margin of the São Lourenço River headwaters, the predominance of Yellow Latosol (Brazilian soil classification) in the upper third of the slope facilitates the water infiltration down to high depths (Figure 2). Going down the slope, the presence of Plintosol (where a lateritic layer occurs) causes water infiltration to low depths and flowing laterally in subsurface. On the slope lower third, there is predominance of Gley soil where water infiltrates at very low depth rapidly reaching the water table and flowing in surface and subsurface, feeding the water course at the end of the slope (Figure 2).

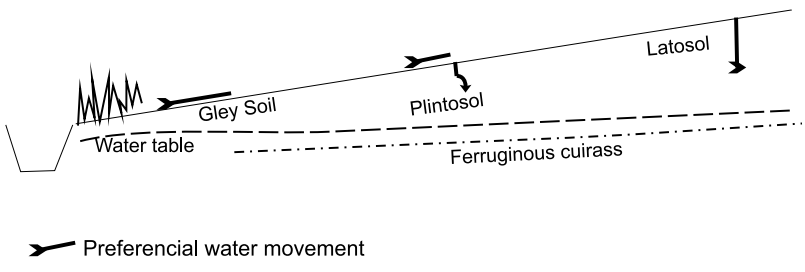

Figure 2. Schematics of water movement in the soil.

Water table was not reached at the upper third of the slope during the dredging investigation due to high depth (bellow $5 \mathrm{~m}$ deep). In the middle third, however, the water table occurred at depths as low as $1 \mathrm{~m}$ emerging at the bottom of the valley.

Regarding pluviosity, which is greatly related to leaching and runoff processes, the highest rain intensity occurred in December and January (Figure 3).

\section{Pesticides usage in the São Lourenço River headwater drainage area}

Despite allowing this study to be carried out in their producing areas, farmers did not give detailed information on pesticides used during this study. So, based on previous

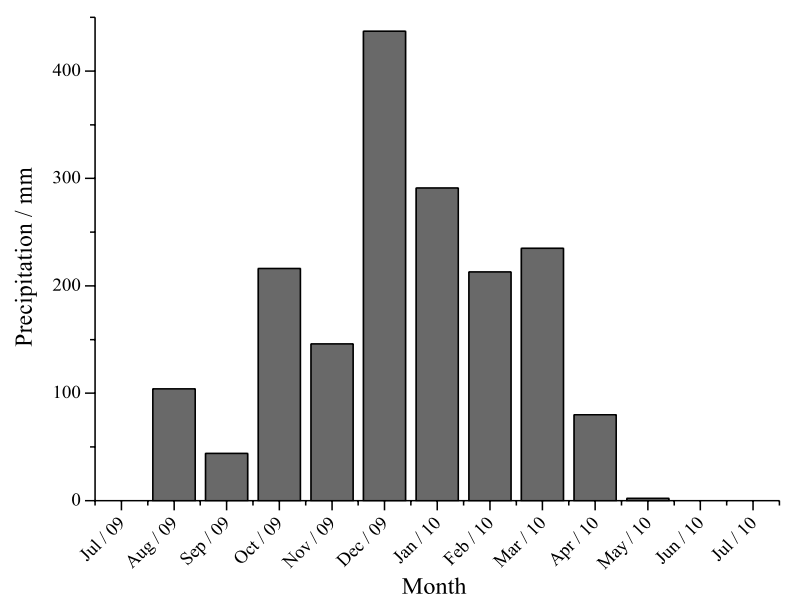

Figure 3. Precipitation from July 2009 to July 2010 in the São Lourenço River headwaters.

studies $^{21,22}$ pesticides atrazine, metolachlor, flutriafol, $\alpha$ - and $\beta$-endosulfan and the metabolites endosulfan sulfate, desethylatrazine (DEA) and desisopropylatrazine (DIA) were selected for analysis (Table 1). They were selected considering the frequency of use on crops usually planted in this region of the Mato Grosso State (soy bean, corn and cotton). During the field work, atrazine pulverization was observed in March 2010. Other applications of pesticides were not confirmed by the field team.

For the discussion about pesticide dynamics, screening criteria (US EPA criteria, ${ }^{25}$ for groundwater contamination potential and the criteria proposed by Goss ${ }^{26}$ for surface water contamination potential) were applied to the pesticides detected in the study region, based on the physical and chemical properties of the pesticides (Table 1). Applicability of these screening criteria to the studied scenario was also evaluated.

\section{Sampling}

In order to understand the pesticide dynamics in the study area, samples of surface water, groundwater,

Table 1. Physical and chemical properties ${ }^{23}$ of analyzed pesticides

\begin{tabular}{|c|c|c|c|c|c|c|c|c|}
\hline Pesticide & Usage class & $\begin{array}{c}\operatorname{Koc}^{\mathrm{a}} / \\
\left(\mathrm{mL} \mathrm{g}^{-1}\right)\end{array}$ & $\begin{array}{c}\text { Water } \\
\text { solubility / } \\
\left(\mathrm{mg} \mathrm{L}^{-1}\right) \\
\end{array}$ & $\log$ Kow $^{b}$ & $\begin{array}{l}\mathrm{DT}_{50}{ }^{\mathrm{c}} \text { in } \\
\text { soil / day }\end{array}$ & $\begin{array}{l}\text { Hydrolysis } \\
\mathrm{DT}_{50} / \text { day }\end{array}$ & $\begin{array}{c}\text { Henry's } \\
\text { constant / } \\
\left(\mathrm{Pa} \mathrm{m}^{3} \mathrm{~mol}^{-1}\right)\end{array}$ & GUS ${ }^{\mathrm{e}}$ index \\
\hline Atrazine & herbicide & 100 & 35 & 2.7 & 75 & 86 & $3.9 \times 10^{-5}$ & 3.75 \\
\hline Metolachlor & herbicide & 200 & 530 & 3.4 & 90 & stable & $1.7 \times 10^{-3}$ & 2.18 \\
\hline Flutriafol & fungicide & 255 & 101 & 2.3 & 1820 & stable & $4.4 \times 10^{-7}$ & 3.46 \\
\hline$\alpha$-Endosulfan & insecticide & 11500 & 0.32 & 3.13 & 50 & 20 & 1.48 & -0.1 \\
\hline$\beta$-Endosulfan & insecticide & 11500 & 0.32 & 3.13 & 50 & 20 & 1.48 & -0.1 \\
\hline Endosulfan & metabolite & 5194 & 0.48 & 3.66 & dd.n.f. & d.n.f. & d.n.f. & - \\
\hline
\end{tabular}

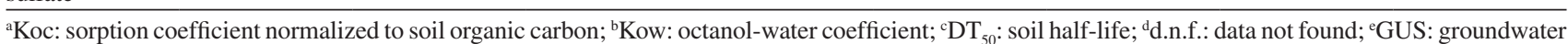
ubiquity score calculated using the equation GUS $=\log \left(\mathrm{DT}_{50}\right.$ soil $) \times(4-\log \mathrm{Koc}){ }^{24}$ 
rainwater, bottom sediment and runoff water and sediment were collected from August 2009 to July 2010. The sampling points used are illustrated in Figure 4.

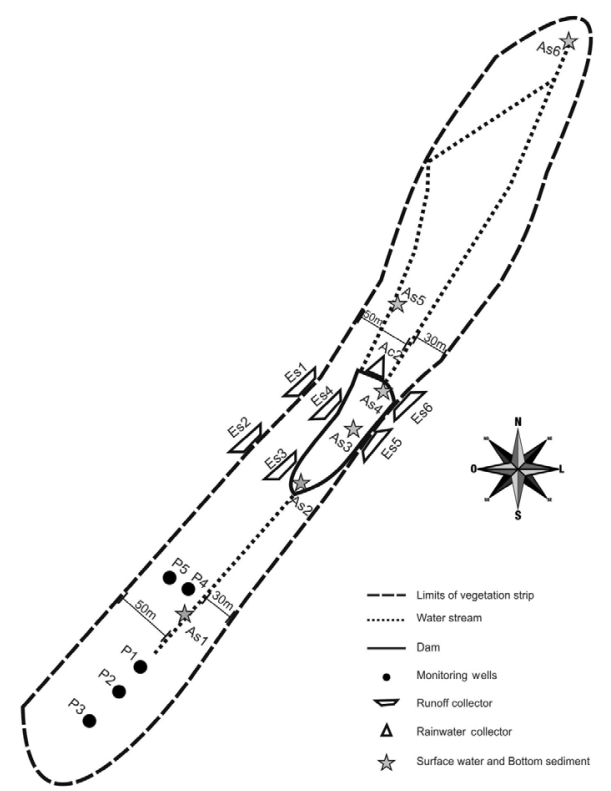

Figure 4. Scheme of sampling point localizations (As: surface water and bottom sediment sampling points, Es: runoff collectors and P: monitoring wells).

Six surface water points were located along the water stream starting with the first point near the spring (AS1) and another 5 points downstream (AS2 to AS6). Two rain water sampling points were selected, the first one (AC1) near to the dam lake, $50 \mathrm{~m}$ far from the plantation limit, and the second one (AC2) near farm houses (not shown in Figure 2) about $1000 \mathrm{~m}$ far from the first one. Five monitoring wells were installed around the headwaters (P1 to P5). Six runoff collecting systems (water and sediment) were installed, four in the left margin (two in the plantation/marginal vegetation limit, ES1 and ES2, and two at $4 \mathrm{~m}$ from the dam margin, ES3 and ES4) and two in the right margin near the dam (ES5 and ES6). Bottom sediment in the water stream was collected at the same sites than surface water (AS1 to AS6).

Rainwater collectors consisted of $4 \mathrm{~L}$ amber glass bottles connected to stainless steel funnels $\left(30 \mathrm{~cm}\right.$ diameter). ${ }^{27}$ Runoff collection system consisted of aluminum gutters (50 cm wide and $50 \mathrm{~cm}$ long) covered with $1 \mathrm{~mm}$ thick aluminum sheets to prevent rainwater from falling directly in the collectors (Figure S2, in the Supplementary Information (SI) section). Water was collected via a tap placed near the gutter bottom and runoff sediment was withdrawn using a stainless steel scoop.

Surface and groundwater and bottom sediment were monthly collected, while rain water and runoff water and sediment were collected after each rain event. Water was directly collected on amber glass bottles and bottom sediment was collected using a Petersen dredge.

Water and sediment samples were collected in $1 \mathrm{~L}$ amber bottle and plastic bags, respectively. Samples were transported on thermal boxes under ice to laboratory where they were kept under refrigeration $\left(4^{\circ} \mathrm{C}\right)$ until analysis.

\section{Chemicals}

Anhydrous sodium sulfate and sodium chloride ACS were from J. T. Baker ${ }^{\oplus}$. Solvents used were: dichloromethane ChromAr from Mallinckrodt, ethyl acetate Nanograde from Mallinckrodt, toluene UltimAR from Mallinckrodt, methanol HPLC grade from Tedia, acetone ACS from QUEMIS and $n$-hexane $95 \%$ UtimAR from Mallinckrodt Chemicals. Bakerbond ${ }^{\mathrm{TM}}$ octadecyl $\left(\mathrm{C}_{18}\right) 40 \mu \mathrm{m}$ Prep LC Packing, J. T. Baker ${ }^{\circledR}$ was used for solid phase extraction.

Pesticide residues were identified and quantified by gas chromatography-mass selective detector using analytical standards from Dr. Ehrenstorfer and Sigma Aldrich with purity $>95 \%$.

\section{Analytical instrumentation}

A gas chromatograph HP-6890 with mass selective detector HP-5973 (Agilent GmbH, Germany), split/splitless injector, automatic sampler and a HP-5MS (5\% phenylmethylsiloxane $)$ column $(30 \mathrm{~m} \times 250 \mu \mathrm{m}$ id $\times 0.25 \mu \mathrm{m}$ phase thickness) was used for pesticide analysis.

Pesticide residues were quantified by GC-MS operated in the selected ion monitoring mode at the following conditions: injector block temperature of $250{ }^{\circ} \mathrm{C}$; carrier gas of helium, gas flow of $1 \mathrm{~mL} \mathrm{~min}^{-1}$; split/splitless injector operated in splitless mode; injection volume of $1 \mu \mathrm{L}$; oven temperature program of initial temperature of $92^{\circ} \mathrm{C}$ held for $2.5 \mathrm{~min}$, heating up to $175^{\circ} \mathrm{C}$ at $15^{\circ} \mathrm{C} \min ^{-1} ; 175^{\circ} \mathrm{C}$ held for $13 \mathrm{~min}$, heating up to $280^{\circ} \mathrm{C}$ at $20^{\circ} \mathrm{C} \mathrm{min}^{-1}, 280^{\circ} \mathrm{C}$ held for $9 \mathrm{~min}$; and transfer-line temperature of $290^{\circ} \mathrm{C}$. Mass spectrometer was operated in electron impact ionization mode (EI) at $70 \mathrm{eV}$. Calibration was performed using deuterated phenanthrene as internal standard. Pesticides were identified by retention time and by relative abundance of three major ions from mass spectra of each substance (Table 2), with a $20 \%$ tolerance.

\section{Sample extraction and analysis}

Pesticides were determined in water by solid phase extraction with octadecilsylane $\left(\mathrm{C}_{18}\right)$ Bakerbond ${ }^{\mathrm{TM}}$, Mallinckrodt Baker, USA. In summary, $500 \mathrm{~mL}$ sample 
Table 2. Retention time $\left(\mathrm{t}_{\mathrm{r}}\right)$ and monitoring ions for each analyte determined by GC/MS (chromatographic conditions in the text)

\begin{tabular}{lcc}
\hline Pesticide & $\mathrm{t}_{\mathrm{r}} / \mathrm{min}$ & SIM ions $^{\mathrm{a}}$ \\
\hline Atrazine & 13.1 & $200.0 ; 215.0 ; 202.0$ \\
DIA & 11.0 & $173.0 ; 158.0 ; 145.0$ \\
DEA & 11.2 & $172.0 ; 174.0 ; 187.0$ \\
Metolachlor & 21.4 & $162.1 ; 238.0 ; 146.0$ \\
Flutriafol & 24.4 & $123.0 ; 164.0 ; 219.0$ \\
$\alpha$-Endosulfan & 24.1 & $240.8 ; 194.9 ; 236.8$ \\
$\beta$-Endosulfan & 25.4 & $194.9 ; 236.8 ; 240.8$ \\
Endosulfan sulfate & 26.1 & $271.8 ; 273.8 ; 228.8$ \\
\hline
\end{tabular}

${ }^{\mathrm{a}}$ Ions used for substance quantification (first ion) and identification (second and third ions) during the selected ion monitoring (SIM).

previously filtered using glass fiber membrane $(0.47 \mu \mathrm{m}$ pore diameter) was preconcentrated through $1000 \mathrm{mg} \mathrm{C}_{18}$ cartridges, previously conditioned with $10 \mathrm{~mL}$ of methanol and $10 \mathrm{~mL}$ of water, followed by elution with subsequent portions of ethyl acetate, hexane-ethyl acetate $(7: 3, v / v)$ and hexane. Extract was concentrated in rotary evaporator to near dryness and transferred to an autosampler vial with toluene to which $0.1 \mathrm{ng}$ of deuterated fenanthrene (100 $\mu \mathrm{L}$ of a ca. $1.000 \mu \mathrm{g} \mathrm{mL}^{-1}$ solution) was added as internal standard. Full details of the method were published elsewhere. ${ }^{28,29}$ Limits of detection ranged from 0.02 to $0.17 \mu \mathrm{g} \mathrm{L}^{-1}$.

Soil and sediment sample extraction method consisted of a solid-liquid extraction step using an acetone, ethyl acetate and water $(2: 2: 1, \mathrm{v} / \mathrm{v} / \mathrm{v})$ solvent mixture with mechanical agitation $(4 \mathrm{~h})$ followed by a liquid-liquid purification step with dichloromethane and final concentration in rotary evaporator. Final extracts were redissolved in toluene and $0.1 \mathrm{ng}$ of deuterated fenanthrene (100 $\mu \mathrm{L}$ of a ca. $1.000 \mu \mathrm{g} \mathrm{mL}^{-1}$ solution) was added as internal standard. Full details of extraction method were previously described. ${ }^{30}$ Limits of detection ranged from 1 to $5 \mu \mathrm{g} \mathrm{kg}^{-1}$.

\section{Results and Discussion}

The discussion of results is based on pesticide properties and environmental conditions. Due to lack of detailed information on pesticide application, the discussion in some cases took into consideration the pesticides most frequently used in the Mato Grosso on the cultures planted during the present study and also on observations made during the sampling campaigns.

\section{Pesticides in surface water}

In surface water, atrazine, metolachlor and flutriafol were detected with 7.2, 4.3 and $7.2 \%$ frequency, respectively. A summary of the data is presented in Table 4 and the pesticide concentration per month in each sampling point is shown in Figure 5.

Among the studied pesticides, limits in water matrices are established only for atrazine, metolachlor and endosulfan by Brazilian legislation (Table 3). The Regulation No. 2914/2011 from the Ministry of Health establishes the limits for potable water. ${ }^{31}$ The National Environmental Council Resolutions No. 357/2005 $5^{32}$ and

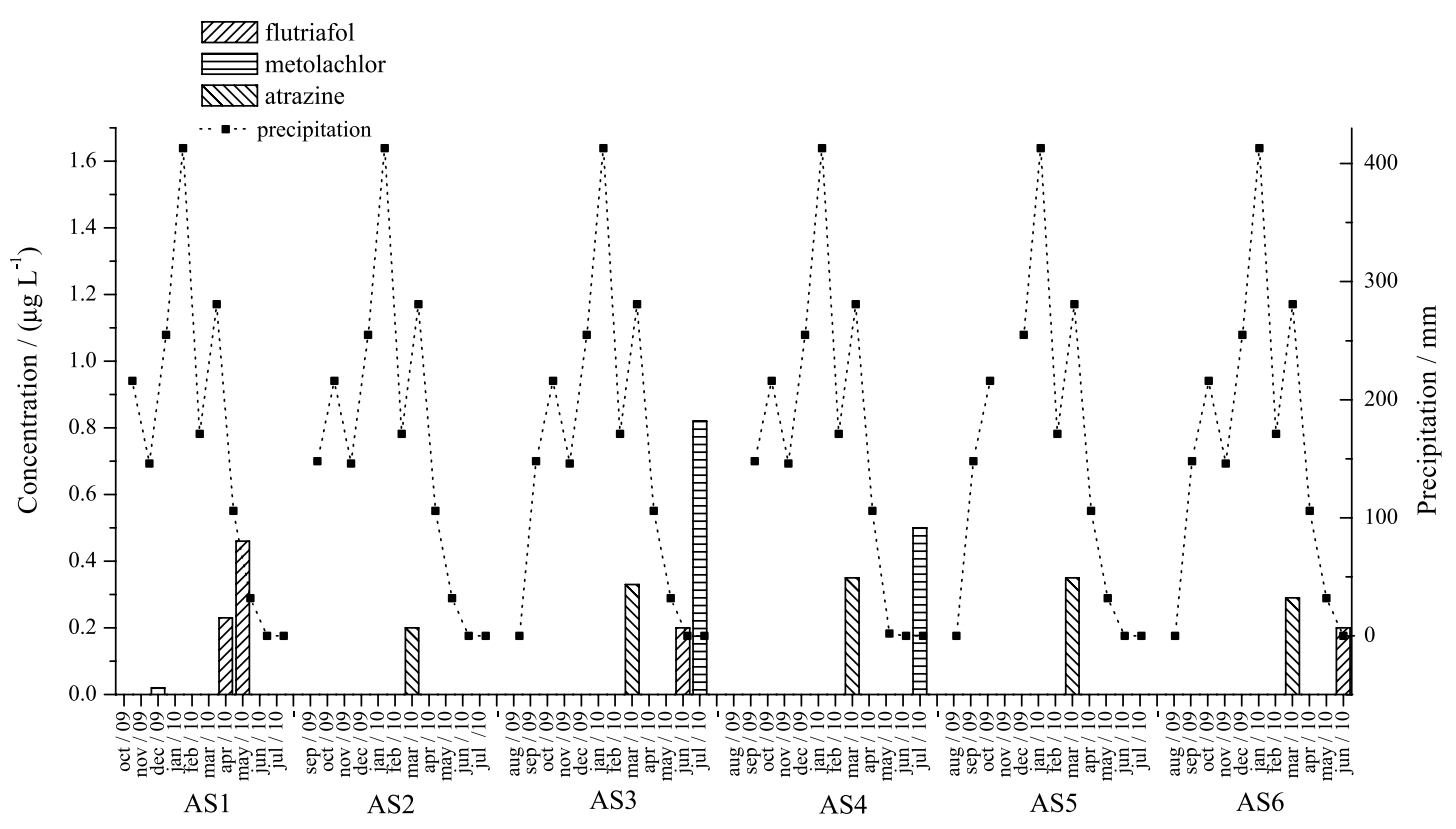

Figure 5. Pesticide concentrations in surface water samples per sampling point and sampling date in the São Lourenço headwaters, Mato Grosso, Brazil. 
$396 / 2008^{33}$ establish the limits for surface and groundwaters, respectively. No legal instrument establishes the limits for pesticides in sediment in Brazil.

Table 3. Limits $\left(\mu \mathrm{g} \mathrm{L}^{-1}\right)$ of the studied pesticides in water established in the Brazilian legislation

\begin{tabular}{lccc}
\hline Pesticide & $\begin{array}{c}\text { Regulation No. } \\
2914 / 2011^{\mathrm{a}}\end{array}$ & $\begin{array}{c}\text { Resolution No. } \\
357 / 2005^{\mathrm{b}}\end{array}$ & $\begin{array}{c}\text { Resolution No. } \\
396 / 2009^{\mathrm{c}}\end{array}$ \\
\hline Atrazine & 2 & 2 & 2 to 10 \\
Metolachlor & 10 & 10 & 10 to 28 \\
Endosulfan & 20 & 20 & 20 to 40 \\
$(\alpha+\beta+$ sulfato $)$ & & & \\
\hline
\end{tabular}

${ }^{a}$ Regulation from the Ministry of Health for potable water; ${ }^{31}$ bresolution from the National Environmental Council for surface waters; ${ }^{32}$ cresolution from the National Environmental Council for groundwater (limits vary depending on the potential use of the groundwater resource). ${ }^{33}$

Comparing the results in Table 4 with the limits in Table 3, it can be seen that in surface and groundwater, there were no concentrations above these limits. Atrazine concentrations above the established limits were found only in rainwater and runoff water that are not matrices included in these regulations. However, the combination of several residues in one sample is not considered in these limits, and potential hazard for environmental organisms may occur as a consequence of several low level residues simultaneously. The European Union, employing the precautionary principle, has established the parametric value in drinking water at a concentration of $0.1 \mu \mathrm{g} \mathrm{L}^{-1}$ for any individual pesticide or $0.5 \mu \mathrm{g} \mathrm{\textrm {L } ^ { - 1 }}$ for total pesticide levels. ${ }^{34}$ If compared to the European Union limits, the great majority of our results were above them. However, since these limits are not based on toxicological or epidemiological data, it would be impossible to assert that there is any eminent risk associated to them.
Flutriafol was detected at point AS1 (near the spring) due to its high leaching potential and persistence that can lead to subsurface flow reaching water emergence point. This point is protected by natural vegetation. In the downstream points, dilution may have reduced the flutriafol concentration down to values below limit of detection. Subsurface flow also explains the detection of this pesticide in points AS3 and AS6 in June, when pesticides are generally not applied in the region. In India, Deb et al. ${ }^{35}$ also reported detection of flutriafol below root level and subsequently in the water table.

Atrazine was detected in almost every point in March due to its application close to the sampling date. This detection is probably due to run-off and/or direct precipitation since March is a period of intense rains. In point AS1, where there is a remaining natural vegetation strip, atrazine was not detected, supporting the above hypothesis.

\section{Pesticides on groundwater}

In contrast to surface water, $\beta$-endosulfan and its metabolite endosulfan sulfate were also detected in groundwater in addition to metolachlor, atrazine and flutriafol (Figure 6 and Table 4).

Flutriafol was detected in subsurface water in concentrations ranging from 0.15 and $0.75 \mu \mathrm{g} \mathrm{L}^{-1}$ in the points P1, P2, P3 and P5. This compound has a very high persistence and presents a high leaching potential due to its high water solubility and low sorption coefficient (Table 1). The shallow water table in this region emerging in the bottom of the valley along with the impermeable layer (Figure 3) that limits rainwater infiltration render the groundwater highly vulnerable to pesticide contamination. This is evidenced by the detection of flutriafol on points $\mathrm{P} 1$ to $\mathrm{P}$ 3, situated on an area with remaining natural vegetation.

Table 4. Pesticide range and frequency of detection in analyzed matrices

\begin{tabular}{|c|c|c|c|c|c|c|c|c|c|c|c|c|}
\hline \multirow[b]{2}{*}{ Pesticide } & \multicolumn{2}{|c|}{ Surface water } & \multicolumn{2}{|c|}{ Groundwater } & \multicolumn{2}{|c|}{ Rainwater } & \multicolumn{2}{|c|}{ Runoff water } & \multicolumn{2}{|c|}{ Runoff sediment } & \multicolumn{2}{|c|}{ Bottom sediment } \\
\hline & $\begin{array}{l}\text { Range / } \\
\left(\mu \mathrm{g} \mathrm{L}^{-1}\right)\end{array}$ & $\%$ & $\begin{array}{l}\text { Range / } \\
\left(\mu \mathrm{g} \mathrm{L}^{-1}\right)\end{array}$ & $\%$ & $\begin{array}{l}\text { Range / } \\
\left(\mu \mathrm{g} \mathrm{L}^{-1}\right)\end{array}$ & $\%$ & $\begin{array}{l}\text { Range / } \\
\left(\mu \mathrm{g} \mathrm{L}^{-1}\right)\end{array}$ & $\%$ & $\begin{array}{l}\text { Range / } \\
\left(\mu \mathrm{g} \mathrm{kg}^{-1}\right)\end{array}$ & $\%$ & $\begin{array}{l}\text { Range / } \\
\left(\mu \mathrm{g} \mathrm{kg}^{-1}\right)\end{array}$ & $\%$ \\
\hline DIA & nd & - & $0.64-0.91$ & 9 & nd & - & $0.33-1.53$ & 44 & nd & - & nd & - \\
\hline DEA & nd & - & nd & - & $1.48-3.31$ & 11 & $1.24-3.70$ & 11 & nd & - & nd & - \\
\hline Atrazine & $0.18-0.35$ & 7 & $0.2-0.28$ & 3 & $0.02-8.2$ & 50 & $0.02-28.3$ & 44 & $7.2-23.1$ & 41 & nd & - \\
\hline Metolachlor & $0.5-0.82$ & 4 & $0.02-1.16$ & 40 & $0.02-0.30$ & 39 & $0.02-0.85$ & 14 & $10.2-56.1$ & 41 & $8.7-137$ & 4.5 \\
\hline Flutriafol & $0.04-0.46$ & 7 & $0.15-0.75$ & 6 & $0.05-0.12$ & 16 & $0.05-0.92$ & 28 & nd & - & nd & - \\
\hline$\alpha$-Endosulfan & nd & - & nd & - & nd & - & nd & - & $3.02-1009$ & 34 & nd & - \\
\hline$\beta$-Endosulfan & nd & - & $0.02-0.33$ & 13 & nd & - & nd & - & $10.7-2218$ & 57 & nd & - \\
\hline Endosulfan sulfate & nd & - & $0.22-0.62$ & 13 & $0.09-0.14$ & 33 & $0.20-8.02$ & 63 & $55.1-15685$ & 57 & $2.0-57.6$ & 18 \\
\hline
\end{tabular}

nd: not detected. 


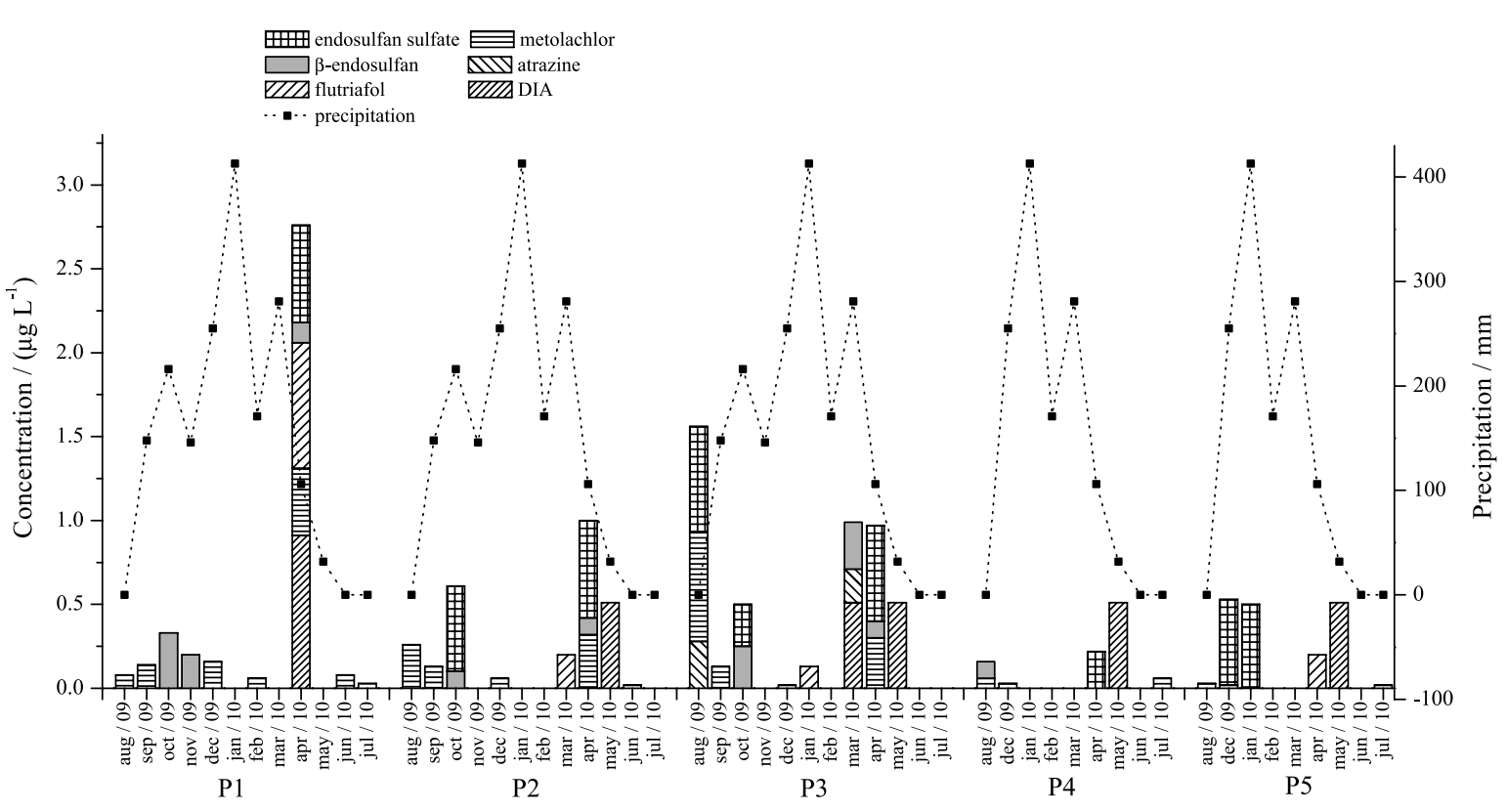

Figure 6. Pesticide concentrations in groundwater samples per sampling point and sampling date in the São Lourenço River headwaters, Mato Grosso, Brazil.

The detection of $\beta$-endosulfan and endosulfan sulfate, considered non leachable by US EPA criteria ${ }^{25}$ due to their high sorption coefficient and low water solubility (Table 1), is related to the shallow water table in addition to the presence of macropores. These macropores in the soil form preferential pathways causing solutes such as pesticides to move with the infiltrating water without interacting with the soil in a process known as preferential flow. ${ }^{36}$ This process was also detected in a nearby region by Reichenberger et al. ${ }^{37}$ Another fact that may have contributed to the frequent detection of endosulfan sulfate on groundwater is the intensive use of its parental compound endosulfan. Although the farmers did not inform the applied pesticides, it is known, from previous studies, ${ }^{9,21}$ that in the Mato Grosso cotton plantation, endosulfan may be applied up to seven times during a crop period. Moreover, endosulfan sulfate is more persistent than its parental isomers. ${ }^{38}$

Other authors also found these compounds on groundwater, such as Dalton and Frick ${ }^{39}$ who evaluated the evolution of pesticides concentrations from 1993 to 2005 in aquifers in Florida, USA. Atrazine, DEA, metolachlor, alachlor, fluometuron and tebutiuron were detected in $20 \%$ of the samples with the metabolite desethylatrazine showing an increase in concentration on the Florida Aquifer during the study period. Atrazine was also detected by Hamilton and Miller $^{40}$ with low frequency (3\%), which may be due to losses by volatilization, mineralization and formation of non-extractable residues on the soil. ${ }^{41}$

Metolachlor was frequently detected (40\%), although in a lower concentration than the other pesticides. In Mato
Grosso, previous studies ${ }^{9,21,27}$ also found metolachlor in groundwater, even in deeper water levels.

\section{Pesticides in rainwater}

Collectors for rainwater were passive pan samplers for collection of pesticide bulk deposition. As it is commonly assumed that dry deposition of pesticides is of minor importance for the total pesticide deposition, ${ }^{42}$ in a first approximation our group regarded the measured concentrations as a consequence of wet deposition.

On both rainwater collectors, atrazine, metolachlor, flutriafol and endosulfan sulfate were detected in high concentration as shown in Figure 7 and Table 4.

The occurrence of pesticides in rainwater indicates that pesticides may be volatilized either from soil and plant surface or at the application moment. In addition, drift is also a probable process of pesticide movement in the atmosphere. The same pesticides detected in surface water were detected in rainwater showing that volatilization and drift are important pathways for these substances to reach superficial water resources.

The high values of atrazine concentration in March when compared to the other months may have been caused by drift since this herbicide was applied near the sample collection date.

Figure 7 shows that concentrations increased from January to March, which are the months with more intensive pesticide application. Our results corroborate the ones found by Lourencetti et al. ${ }^{43}$ who, similarly, detected $\beta$-endosulfan, endosulfan sulfate, metolachlor, 


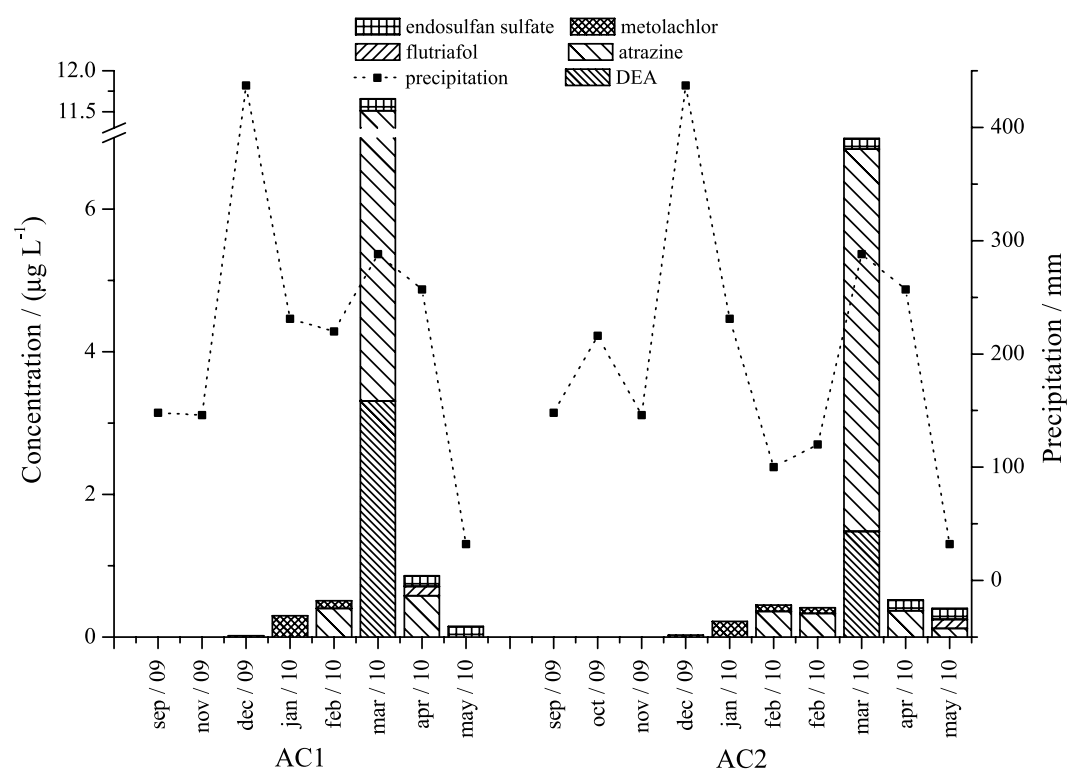

Figure 7. Pesticide concentrations in rainwater samples per sampling point and sampling date in the São Lourenço River headwaters, Mato Grosso, Brazil.

atrazine and flutriafol in rainwater with high frequency, in concentrations ranging from 0.02 to $47.2 \mu \mathrm{g} \mathrm{L}^{-1}$ in the Lucas do Rio Verde City, Center of the Mato Grosso State.

Some of these pesticides were also detected by Quaghebeur et al. ${ }^{44}$ who initiated a pesticide monitoring study in rainwater in Flandres, Belgium. The authors observed that the most frequently detected ones were $\alpha, \beta$-endosulfan and endosulfan sulfate, atrazine, diuron, glyphosate and isoproturon from 1997 to 1999. Moreover, these authors reported that the frequency of detection was related to local pesticide pulverization. ${ }^{44}$ In contrast, Murti and $\mathrm{Nag}^{45}$ (in a study involving ten European countries) observed that some of the pesticides monitored were not used on the agricultural areas where the rain samples were collected, indicating long distance transport of these compounds in the atmosphere.

\section{Pesticides in runoff water}

The same pesticides detected in rain, surface and groundwater were detected in runoff water but in much higher concentrations and frequencies of detection (Figure 8 and Table 4).

The collection points AE3 and AE4 were installed between the vegetation strip and the dam on the left margin where a vegetation recovery process is already under way, while the points AE1 and AE2 on the left margin and AE5 and AE6 on the right margin were located at the inferior limit of the plantation area. No significant effect of the vegetation was observed for the pesticide concentration in runoff water as have been reported in several studies that investigated the effects of buffer strips on pesticide levels during simulated runoff such, as those carried out by Moore et al. ${ }^{46}$ and Poletika et al ${ }^{47}$ or under natural rain as the one carried out by Liess et al. ${ }^{48}$ These authors pointed out that the positive effect of the buffer vegetation is mainly due to the smaller losses of water and sediment during runoff.

The higher atrazine concentration in March accompanied its higher concentration on surface water, confirming its application during this month. The pesticide losses from the field by runoff depend, among other factors, upon the time interval between application and the next intense rain event. In June and July, there was no rain event strong enough to cause runoff.

The frequent detection of endosulfan sulfate (63\%) reinforces the hypothesis that endosulfan was used in the region. According to the Brazilian National Agency for Sanitary Vigilance (ANVISA), endosulfan will be withdrawn from Brazilian market in three years' times from July $31^{\text {st }}, 2010$, since it was considered dangerous to health and the environment. ${ }^{49} \mathrm{Also}$, at the fifth Meeting of the Conference of the Parties to the Stockholm Convention held on April 25-29, 2011, the inclusion of endosulfan in the list of Persistent Organic Pollutants was discussed and approved to enter into force in one year. The environmental behavior of endosulfan with the possibility of atmosphere transport added to the potential health effects of this substance were the main reasons for this inclusion.

\section{Pesticides in runoff sediment}

Very high concentrations of endosulfan sulfate were detected in runoff sediment samples collected at points 


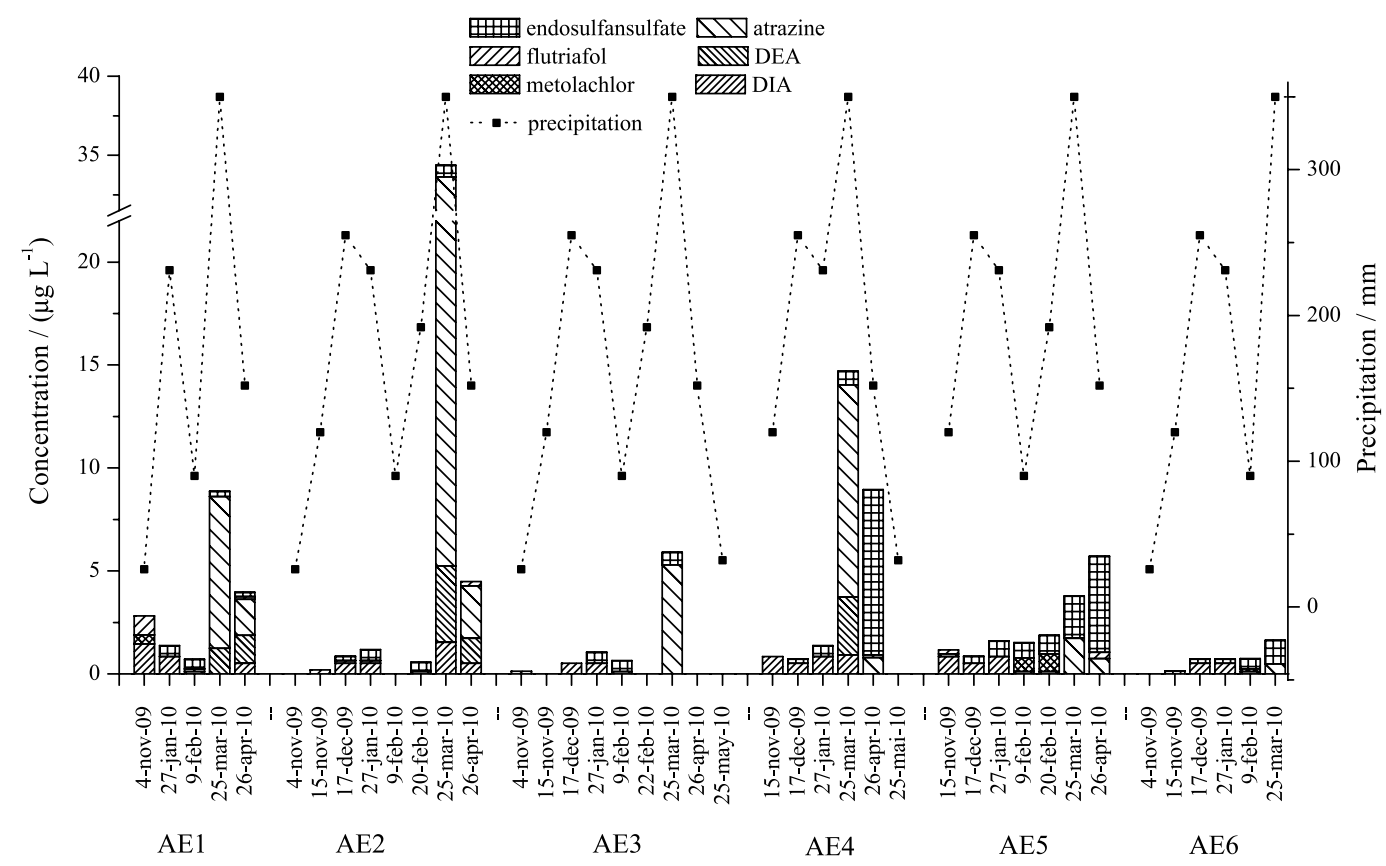

Figure 8. Pesticide concentrations in runoff water samples per sampling point and sampling date in the São Lourenço River headwaters, Mato Grosso, Brazil.

AS5 and AS6, which are at the bottom of the slope without any protection from vegetation (Figure 9 and Table 4).

The highest concentrations of pesticides on the transported sediment were mainly detected at points SE5 and SE6, which are closer to the plantation border. Comparing runoff water and sediment atrazine, metolachlor and endosulfan sulfate were detected in both matrices.

As observed for the other sample matrices, atrazine concentration increased in March. Endosulfan sulfate, which presents high soil sorption coefficient, was detected in higher concentrations. From March on $\alpha$ - and $\beta$-endosulfan were also detected, only at the sampling points SE5 and SE6, indicating that this pesticide was applied on the plantation at the right margin of the dam.

The reduced concentration of $\alpha$-endosulfan when compared to $\beta$-endosulfan, despite its dominance in the applied pesticide formulation (66-70\% of the active ingredient mass in the formulation is comprised of $\alpha$-endosulfan), was also observed by other authors, ${ }^{27,50,51}$ indicating a decreased persistence of the $\alpha$-isomer in aquatic system in comparison to the $\beta$-isomer.

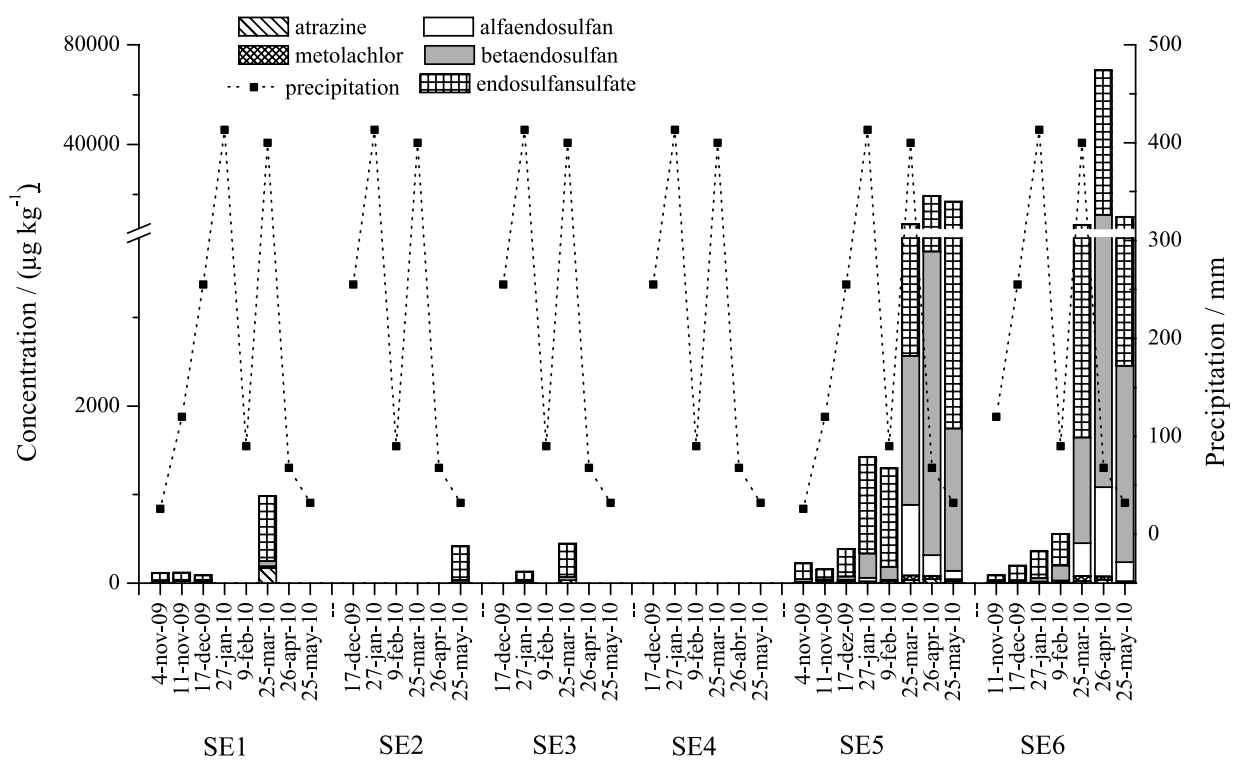

Figure 9. Pesticide concentrations in runoff sediment samples per sampling point and sampling date in the São Lourenço headwaters, Mato Grosso, Brazil. 
The detection percentage of pesticides in runoff sediment was higher than in other matrices, endosulfan sulfate and $\beta$-endosulfan were detected in $57 \%$ of the samples, metolachlor and atrazine in $41 \%$ and $\alpha$-endosulfan in $34 \%$.

No pesticide residue was detected at point SE4 that is located between the vegetation strip and the dam. This observation can be justified by the occurrence of two processes in the vegetation strip: (i) it can retain part of the carried sediment allowing the pesticide residues to be degraded or leached in the soil profile, reducing the availability to be carried out by runoff; ${ }^{52}$ (ii) the organic residues at the vegetation strip increase the retention of pesticides and the reduced flow due to the physical barrier imposed by this strip allows a higher residence time in this compartment with an enhanced dissipation. ${ }^{46,53}$ As an example, Poletika et al. ${ }^{47}$ determined the reduction of pesticide runoff under simulated rain condition in Sioux County (USA) and measured a total reduction of $62 \%$ for atrazine.

As observed, the runoff process transport not only soil particles but also the pesticides and may cause impacts such as siltation and increased pollution negatively affecting the aquatic fauna and flora, emphasizing the importance of retention barriers to reduce their entrance in the water bodies. ${ }^{54,55}$

\section{Pesticides in bottom sediment}

In bottom sediment, only metolachor and endosulfan sulfate were detected (Figure 10 and Table 4). At least one analyte was detected in 19\% of the analyzed samples.
The pesticides metolachlor and endosulfan are frequently used in agriculture in the Mato Grosso State, particularly in cotton plantation and their detection in the bottom sediment can be a consequence of runoff as they were also found in runoff sediment allied to the reduced presence of natural vegetation. The detection of metolachlor over the whole period of study indicates persistent pollution, as observed by Carabia-Martínez et al. ${ }^{56}$ in Spain and Dores et al. ${ }^{22}$ in this same state in a region near to our study region.

The Brazilian legislation does not determine pesticide limits on sediments. Crommentuijn et al. ${ }^{57}$ reported limits established in Holland for pesticides in water, soil and sediment aiming environmental protection. For endosulfan in sediment, the threshold is $0.026 \mu \mathrm{g} \mathrm{kg}^{-1}$ and for metolachlor $2.5 \mu \mathrm{g} \mathrm{kg}^{-1}$. The determined concentration of metolachlor ( 8.7 to $137 \mu \mathrm{g} \mathrm{kg}^{-1}$ ) indicates possible adverse effects to aquatic biota. Although a limit was established for endosulfan and not for its metabolite, endosulfan sulfate is even more toxic than its parental compound,,$^{51,58}$ so the determined concentrations ( 2.0 to $57.6 \mu \mathrm{g} \mathrm{kg}^{-1}$ ) also indicate risk for the aquatic biota.

Endosulfan sulfate was also frequently detected in sediments of the São Lourenço River in sampling points further downstream than the ones of our study indicating that this metabolite might accumulate in the sediment compartment of this river. ${ }^{27}$ However, Miranda et al..$^{59}$ analyzed pesticides in bottom sediments on the Pantanal (Mato Grosso and Mato Grosso do Sul States, Brazil) in 2003-2004 and did not detect this metabolite. A more detailed study should be necessary to evaluate if endosulfan sulfate may present a risk to the Pantanal.

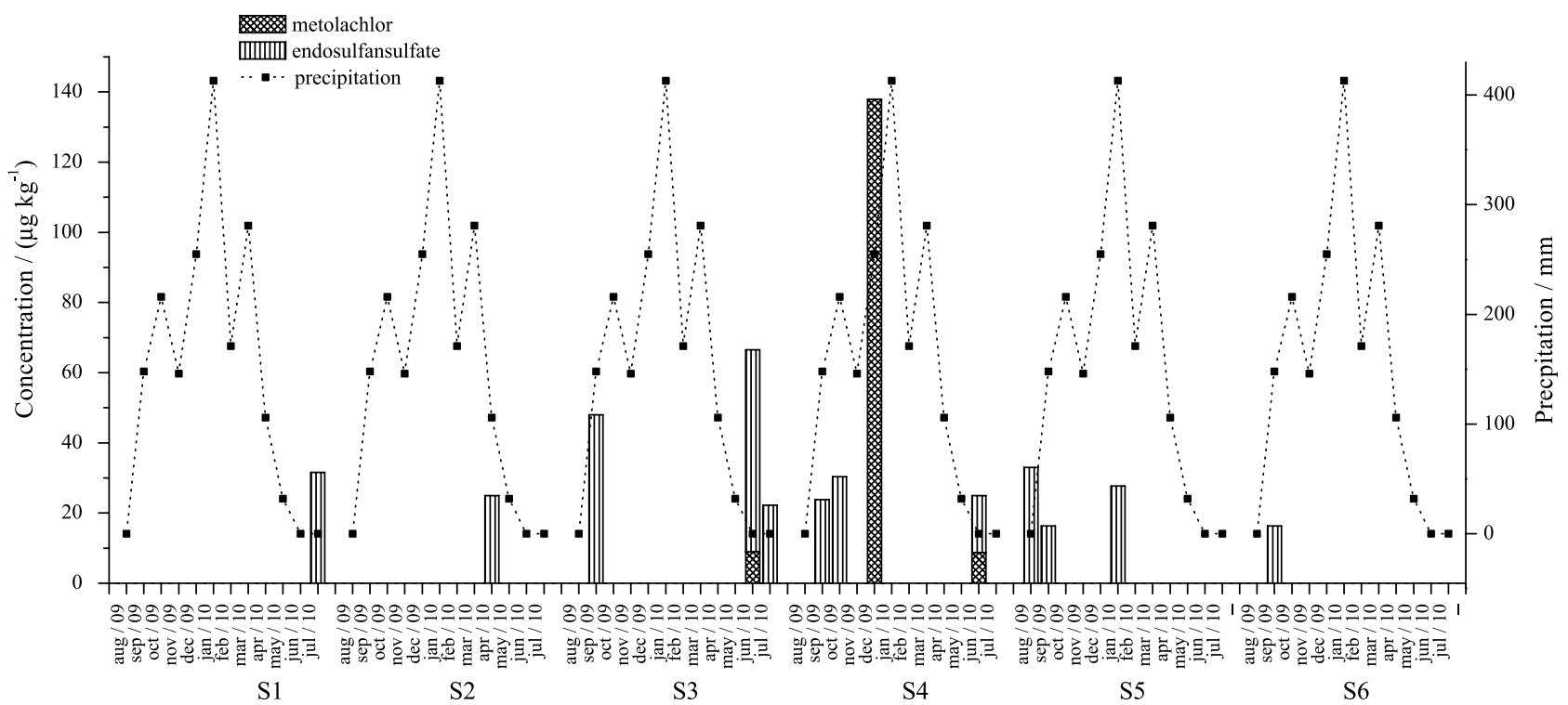

Figure 10. Pesticide concentrations in bottom sediment samples per sampling point and sampling date in the São Lourenço River headwaters, Mato Grosso, Brazil. 
General discussion on pesticide dynamics in the study area

The classification of the detected pesticides according to their potential for groundwater contamination and runoff either dissolved in water or sorbed to sediment is presented in Table 5. The applicability of the screening criteria to the studied scenario of tropical soil and climate was carried on by comparing the results presented in Table 4 and the predicted contamination potential (US EPA criteria ${ }^{25}$ and Goss criteria $^{26}$ ).

Pesticides detected in bottom sediment were also detected in runoff sediment. Those classified as having medium to high contamination potential of water resources by runoff were found in runoff sediment. Atrazine, $\alpha$ - and $\beta$-endosulfan were not detected in bottom sediment. In addition, concentrations in runoff sediment were higher than in bottom sediment due to the protection of the remaining marginal vegetation, dilution effect due to sediment transport from upstream and also due to the degradation of pesticides.

All pesticides considered potential contaminants when dissolved in water were detected in runoff water. Atrazine, metolachlor and flutriafol were also detected in surface water in lower concentrations than in runoff water. The vegetation strip and the dilution effect may have contributed for this reduced concentration. DIA, DEA and endosulfan sulfate were not detected in surface water, despite being present in runoff water.

All pesticides that are considered potential groundwater contaminants were detected on the water table and well samples. On the other side, $\beta$-endosulfan and endosulfan sulfate that present low leaching potential were detected in groundwater. This is due to its intensive use and to preferential flow that is common in this region soil. ${ }^{37}$

Endosulfan, atrazine, metolachlor and flutriafol were also detected in rainwater. Some properties of the pesticides and environment can explain the presence of these substances in rainwater. Since pesticides with vapor pressure higher than $10^{-4} \mathrm{~Pa}$ are considered volatile according to FOCUS (Forum for the Coordination of Pesticide Fate Models and their Use), ${ }^{60}$ among the analyzed pesticides, trifluralin, metolachlor and $\alpha$ - and $\beta$-endosulfan can be classified as such. Atrazine is less volatile while flutriafol is nonvolatile, what indicates that drift may have occurred during application confirming their application in the studied region. Also, high air temperatures (maximum temperatures of up to $35^{\circ} \mathrm{C}$ ) common in this area may enhance volatilization.

Thus, it can be concluded that the screening criteria used here predicted with good accordance the surface and groundwater contamination by pesticides in the conditions of the present study.

\section{Conclusions}

Several pesticides were detected in different environmental matrices such as surface and groundwater and bottom sediment in the São Lourenço River headwaters (Mato Grosso State), showing the high vulnerability of this region to pesticide contamination. Runoff process showed to be an important pathway for surface water resource contamination, alerting to the importance of the strip of natural vegetation maintenance. Atmospheric transport (volatilization and drift) could also have been a source of pesticide contamination to surface waters. The study area is also highly vulnerable to leaching due to the hydric behavior of the slope and low depth of water table. It is important to emphasize that headwater draining areas are naturally vulnerable to contamination by different pathways, fact that was confirmed in this study. Nowadays, the Brazilian Congress is discussing the new Forest Code and studies such as this one emphasize the importance of the so called Permanent Preservation Areas (APPs), which include river marginal vegetation and the vegetation around headwater drainage areas.

\section{Acknowledgments}

The authors thank Conselho Nacional de Desenvolvimento Científico e Tecnológico (CNPq) for financial support, Coordenação de Aperfeiçoamento de Pessoal de Nível Superior (CAPES) for K. P. Casara and C. Lourencetti scholarship and the farmers of the study region for allowing access to the study area.

\section{Supplementary Information}

Supplementary material is available free of charge at http://jbcs.sbq.org.br as PDF file.

\section{References}

1. Spadotto, C. A.; Filizola, H.; Gomes, M. A. F.; Pesticidas: R. Ecotoxicol. Meio Amb. 2001, 11, 127.

2. Carter, A.; Pestic. Outlook 2000, 11, 149.

3. Wauchope, R. D.; J. Environ. Qual. 1978, 7, 459.

4. Dores, E. F. G. C.; Spadotto, C. A.; Weber, O. L. S.; Carbo, L.; Vecchiato, A. B.; Pinto, A . A.; Water, Air, Soil Pollut. 2009, 197, 175.

5. Cooper C. M.; J. Freshwater Ecol. 1991, 6, 237.

6. Correia, F. V.; Langenbach, T.; Rev. Bras. Ciênc. Solo 2006, 30 , 183.

7. Mansingh, A.; Robinson, D. E.; Henry, C.; Lawrence, V.; Environ. Monit. Assess. 2000, 63, 459. 
8. Azevedo, D. A.; Gerchon, E.; Reis, E. O.; J. Braz. Chem. Soc. 2004, 15, 292.

9. Martins, E. L.; Dores, E. F. G. C.; Weber, O. L. S.; Spadotto, C. A.; J. Environ. Sci. Health, Part B 2007, 42, 877.

10. Inoue, M. H.; Oliveira Jr., R. S.; Constantin, J.; Alonso, D. G.; Santana, D. C.; Acta Sci., Agron. 2008, 30, 631.

11. Oliveira, V. S.; Lima, J. M.; Carvalho, R. F.; Rigitano, R. L. O.; Quim. Nova 2009, 32, 1432.

12. Queiroz, S. C. N.; Ferracini, V. L.; Gomes, M. A. F.; Rosa, M. A.; Quim. Nova 2009, 32, 378.

13. Azevedo, D. A.; Silva, T. R.; Knoppers, B. A.; Schulz-Bull, D.; J. Braz. Chem. Soc. 2010, 21, 1096.

14. Martinazzo, R.; Jablonowski, N. D.; Hamacher, G.; Dick, D. P.; Burauel, P.; J. Agric. Food Chem. 2010, 58, 7864.

15. Peret, A. M.; Oliveira, L. F.; Bianchini Jr., I.; Seleghim, M. H. R.; Peret, A. C.; Mozeto, A. A.; Chemosphere 2010, 78, 1225.

16. Antes, F. G.; Krupp, E.; Flores, E. M. M.; Dressler, V. L.; Feldmann, J.; Environ. Sci. Technol. 2011, 45, 10524.

17. Chelinho, S.; Lopes, I.; Natal-da-Luz, T.; Domene, X.; Nunes, M. E. T.; Espíndola, E. L. G.; Ribeiro, R.; Sousa, J. P.; Environ. Toxicol. Chem. 2012, 31, 437.

18. Código Florestal Brasileiro, Lei No. 4.771 de 15 de setembro de 1965, http://www.controleambiental.com.br/codigo_florestal.htm accessed in August 2012.

19. http://monitoramento.sema.mt.gov.br/navegadores/MapaCar. html accessed in August 2012.

20. Salomão, F. X. T.; Castro, S. S.; GEOUSP - Espaço e Tempo, 2000, 7, 27.

21. Dores, E. F. G. C.; Monnerat, R. G.; Vecchiato, A. B. In Algodão: Pesquisas e Resultados para o Campo; Moresco, E., ed.; Facual, 2: Cuiabá, Mato Grosso, Brasil, 2006, chapter 15.

22. Dores, E. F. G. C.; Carbo, L.; Ribeiro, M. L.; De-Lamonica-Freire, E. M.; J. Chromatogr. Sci. 2008, 46, 585.

23. http://sitem.herts.ac.uk/aeru/footprint/en/index.htm accessed in August 2012.

24. Gustafson, D. I.; Environ. Toxicol. Chem. 1989, 8, 339.

25. Cohen, S. Z.; Wauchope, R. D.; Klein, A. W.; Eadsporth, C. V.; Graney, R.; Pure Appl. Chem. 1995, 67, 2109.

26. Goss, D. W.; Weed Technol. 1992, 6, 701.

27. Laabs, V.; Amelung, W.; Pinto, A. A.; Wantzen, M.; Silva, C. J.; Zech, W.; J. Environ. Qual. 2002, 31, 1636.

28. Dores, E. F. G. C.; Navickiene, S.; Cunha, M. L. F.; Carbo, L.; Ribeiro, M. L.; De-Lamonica-Freire, E. M.; J. Braz. Chem. Soc. 2006, 17,866 .

29. Laabs, V.; Amelung, W.; Pinto, A. A.; Altstaedt, A.; Zech, W.; Chemosphere 2000, 41, 1441.

30. Laabs, V.; Amelung, W.; Zech, W.; J. Environ. Qual. 1999, 28, 1778.

31. Ministério de Estado da Saúde, Portaria No. 2914 de 12 de dezembro de 2011, Brasil http://portal.saude.gov.br/portal/arquivos/ pdf/portaria_2914_12_12_2011.pdf accessed in August 2012.
32. Conselho Nacional de Meio Ambiente (CONAMA), Resolução No. 357 de 17 de março de 2005, Brasil, http://www.mma. gov.br/port/conama/res/res05/res35705.pdf accessed in August 2012.

33. Conselho Nacional de Meio Ambiente (CONAMA), Resolução No. 396 de 3 de abril de 2008, Brasil, http://www.mma.gov.br/ port/conama/legiabre.cfm?codlegi=562 acessed in August 2012.

34. Council Directive 98/83/EC on the Quality of Water Intended for Human Consumption OJ L 330, 5.12.1998, p. 32-54.

35. Deb, D.; Engel, B. A.; Harbor, J.; Hahn, L.; Lim, K.J.; Zhai,T.; Water Air Soil Pollut. 2010, 207, 273.

36. McGrath, G. S.; Hinz, C.; Sivapalan, M.; Water Resour. Res. 2009, 45, W11405.

37. Reichenberger, S.; Amelung, W.; Laabs, V.; Pinto, A. A.; Totsche, K. U.; Zech, W.; Geoderma 2002, 110, 63.

38. Silva, F. de A; Lourencetti, C; Dores, E. F.G. C.; Quím. Nova 2010, 33, 1457.

39. Dalton, M. S.; Frick, E. A.; J. Environ. Qual. 2008, 37, 264.

40. Hamilton, P. A.; Miller, T. L.; J. Soil Water Conserv. 2002, 57, 16.

41. Correia, F. V.; Mercante, F. M.; Fabrício, A. C.; Campos, T. M. P.; Junior, E. V.; Langenbach, T.; Pesticidas: R. Ecotoxicol. Meio Amb. 2007, 17, 37.

42. Dubus, I. G.; Hollis; J. M. Brown; C. D.; Environ. Pollut. 2000, 110,331 .

43. Nogueira, E. N.; Dores, E. F. G. C.; Pinto, A. A.; Amorim, R. S. S.; Ribeiro, M. L.; Lourencetti, C.; J. Braz. Chem. Soc. 2012, 23, 1476.

44. Quaghebeur, D.; de Smet, B.; de Wulfa, E.; Steurbaut, W.; J. Environ. Monit. 2004, 6, 182.

45. Murti, C. R. K.; Nag, D. In Chemistry, Agriculture and the Environment; Richardson, M. L., ed.; The Royal Society of Chemistry: Cambridge, DC, 1991.

46. Moore, M. T.; Denton, D. L.; Cooper, C. M.; J. Environ. Qual. 2008, 37, 486.

47. Poletika, N. N.; Coody, P. N.; Fox, G. A.; Sabbagh, G. J.; Dolder, S. C.; White, J.; J. Environ. Qual. 2009, 38, 1042.

48. Liess, M.; Schulz, R.; Liess, M. H.-D.; Rother, B.; Kreuzig, R.; Water Res. 1999, 33, 239.

49. Agencia Nacional de Vigilância Sanitária (ANVISA); Regulamento Técnico para o Ingrediente Ativo Endossulfam em decorrência da Reavaliação Toxicológica, ResoluçãoRE No. 28, 2010, http://www.brasilsus.com.br/legislacoes/ resolucoes/105067-28.html accessed in August 2012.

50. Navarro, S.; Barba, A.; Segura, J. C.; Oliva, J.; Pestic. Manag. Sci. 2000, 56, 849.

51. Leonard, A. W.; Hyne, R. V.; Lim, R. P.; Leigh, K. A.; Le, J.; Beckett, R.; J. Environ. Qual. 2001, 30, 750.

52. Baughman, T. A.; Shaw, D. R.; Webster, E. P.; Boyette, M.; Weed Technol. 2001, 15, 184.

53. Liu, X.; Zhang, X.; Zhang, M.; J. Environ. Qual. 2008, 37, 667. 
54. Ludovice, M. T. F.; Roston, D. M.; Teixeira-Filho, J.; Rev. Bras. Eng. Agric. Amb. 2003, 7, 323.

55. Otto, S.; Vianello, M.; Infantino, A.; Zanin, G.; Guardo, A. D.; Chemosphere 2008, 71, 74.

56. Carabia-Martínez, R. E. R.; Gonzalo, E.; Herrero-Hernandez, F. J. S.; Flores, M. G. P.; J. Chromatogr., A 2002, 950, 157.

57. Crommentuijn, T.; Sijm, D.; De Bruijn, J.; Van Leeuwen, K.; Van De Plassche, E.; J. Environ. Manag. 2000, 58, 297.

58. White-Stevens, R.; Pesticides in the Environment; Marcel Dekker: New York, 1971.
59. Miranda, K. A.; Cunha, M. L. F.; Dores, E. F. G. C.; Calheiros, D. F.; J. Environ. Sci. Health, Part B 2008, 43, 717.

60. Forum for the Coordination of Pesticide Fate Models and their Use (FOCUS); Pesticides in Air: Considerations for Exposure Assessment, Report of the FOCUS Working Group on Pesticides in Air, EC Document Reference No. SANCO/10553/2006 Rev 2 June 2008. p. 327.

Submitted: December 12, 2012 Published online: September 13, 2012 